\title{
THE REALITIES OF THE PRESENT AND FUTURE PROSPECTS OF DRINKING AND TECHNOLOGICAL WATER
}

\author{
A. Dolinsky, O. Obodovych, V. Sydorenko \\ Institute of Engineering Thermophysics of the National Academy \\ of Sciences of Ukraine \\ N. Husiatynska \\ National University of Food Technologies
}

\begin{tabular}{|c|c|}
\hline Key words: & ABSTRACT \\
\hline $\begin{array}{l}\text { Artesian water } \\
\text { Water treatment } \\
\text { Aerator-oxidizer } \\
\text { Frequency ofpulsations } \\
\text { Shear rate of flow } \\
\end{array}$ & $\begin{array}{l}\text { The article analyzes the environmental problems of Ukraine } \\
\text { related to the pollution of the Dnipro River as the main source } \\
\text { of drinking and technological water supply. The necessity of } \\
\text { using artesian waters for drinking water supply is substantiated. } \\
\text { The basic problems of quality due to the presence of pollutants }\end{array}$ \\
\hline $\begin{array}{l}\quad \text { Article history: } \\
\text { Received 14.03.2018 } \\
\text { Received in revised form } \\
\text { 26.03.2018 } \\
\text { Accepted } 10.04 .2018 \\
\end{array}$ & $\begin{array}{l}\text { in the artesian water are determined. The analysis of modern } \\
\text { aeration methods of iron removal from water was carried out. } \\
\text { The description and principle of the operation of new techno- } \\
\text { logical equipment for the intensification of the purification of } \\
\text { artesian water from iron compounds is presented. The efficien- }\end{array}$ \\
\hline $\begin{array}{l}\text { Corresponding author: } \\
\text { N. Husiatynska } \\
\text { E-mail: } \\
\text { npnuht@ukr.net }\end{array}$ & $\begin{array}{l}\text { cy of iron removal trom artesian water by discrete-pulse energy } \\
\text { input in the aeration water treatment is determined. } \\
\text { The results of experimental studies of iron removal from } \\
\text { artesian water during various treatment regimes and design } \\
\text { features of an aerator-oxidizer are given. The energy and } \\
\text { technological parameters of the proposed method of artesian } \\
\text { water treatment are given in comparison with the correspon- } \\
\text { ding indicators of other methods of iron removal. The rational } \\
\text { parameters of the process taking into account the energy and } \\
\text { technological characteristics of the proposed method are } \\
\text { established. It is determined that the proposed method of } \\
\text { artesian water treatment contributes to the solution of envi- } \\
\text { ronmental problems at the expense of energy-saving heat } \\
\text { and mass exchange equipment for the preparation of drin- } \\
\text { king and technological water. }\end{array}$ \\
\hline
\end{tabular}

DOI: $10.24263 / 2225-2924-2018-24-2-30$

\section{РЕАЛІЇ СЬОГОДЕННЯ ТА ПЕРСПЕКТИВИ МАЙБУТНЬОГО ПІДГОТОВКИ ПИТНОї І ТЕХНОЛОГІЧНОї ВОДИ}

\author{
А.А. Долінський, О.М. Ободович, В.В. Сидоренко \\ Інститут технічної теплофізики НАН Украӥни \\ Н.А. Гусятинська \\ Національний університет харчових технологій
}

У статті проаналізовано екологічні проблеми України, пов'язані із забрудненням р. Дніпр як основного джерела питного й технологічного 
водопостачання. Обтрунтовано необхідність використання артезіанських вод для питного водопостачання. Визначено основні проблеми якості, зумовлені наявністю забруднюючих речовин у складі артезіанської води. Проведено аналіз сучасних аераційних методів знезалізнення води. Представлено опис $i$ принщип дії нового технологічного обладнання для інтенсифікації очищення артезіанської води від сполук заліза. Визначено ефективність знезалізнення артезіанської води шляхом дискретно-імпульсного введення енергї в процесі аераційної обробки води.

Наведено результати експериментальних досліджень знезалізнення артезіанської води за різних режсиів обробки та конструктивних особливостей аератора-окиснювача, енергетичні й технологічні показники запропонованого способу очищення артезіанської води порівняно з відповідними показниками інших способів знезалізнення. Встановлено рачіональні параметри прочесу з урахуванням енергетичних $і$ технологічних характеристик запропонованого способу. Визначено, що запропонований спосіб очищення артезіанської води сприяє вирішенню екологічних проблем за рахунок енергозберігаючого тепломасообмінного обладнання для підготовки питної та технологічної води.

Ключові слова: артезіанська вода, водоочищення, аератор-окиснювач, частота пульсацій, швидкість зсуву потоку.

Постановка проблеми. Вода - це природне надбання людства, необхідна умова його життедіяльності. Забезпечення населення якісною питною водою сприяє поліпшенню і збереженню здоров'я населення, посиленню безпеки нації в цілому. За прогнозами ООН, до середини третього десятиліття XXI ст. більше 4 млрд людей відчуватимуть нестачу води питної якості, що пов'язано як зі змінами клімату, так і з діяльністю людини. На сьогодні близько $90 \%$ поверхневих і $30 \%$ підземних вод, що забираються для потреб водопостачання, підлягають додатковому очищенню [1].

За даними ЮНЕСКО, серед 122 країн світу Україна посідає 95 місце за рівнем раціонального використання водних ресурсів та якості води [2]. Екологічний стан поверхневих водних об'єктів і якість води в них є основними чинниками санітарного та епідемічного благополуччя населення. Досягнення безпечного для здоров'я людини стану навколишнього природного середовища $є$ пріоритетом сталого розвитку України, що вимагає забезпечення дотримання санітарно-гігієнічних вимог до якості поверхневих вод i нормативних вимог до джерел централізованого питного водопостачання. Серед національних пріоритетів в Україні визнана програма «Якісна вода» [3], спрямована на забезпечення населення України якісною питною водою. Стратегічною метою цієї програми є досягнення європейських показників у дотриманні одного з основних прав людини - права на якісну питну воду. Одночасно мають бути виконані завдання $з$ оптимізації водопостачання всіх галузей промисловості, де технологічні процеси потребують використання води лише питного призначення.

Тому сьогодні актуальним $\epsilon$ впровадження енергоощадного тепломасообмінного обладнання для підготовки питної й технологічної води 3 метою 
більш ефективного вирішення екологічних проблем і проблем охорони навколишнього середовища.

Головним джерелом питного й технологічного водопостачання $є$ поверхневі та підземні води. Для України основним поверхневим джерелом питної й технологічної води $є$ річка Дніпро. Проте останні 20 років через незадовільну екологічну ситуацію та високий рівень забруднення вода р. Дніпро стає малопридатною для питного водопостачання.

Майже всі поверхневі джерела водопостачання України за рівнем забруднення наближаються до 3-го класу якості (розбавлені стічні води), а за міжнародною класифікацією - до 4-го класу (стічні води) [4].

У p. Дніпро щороку близько 10 тис. підприємств скидають понад 10 км $^{3}$ стічних вод, 3 яких 15\% - це скидні води без очищення. Внаслідок техногенних чинників вода забруднена отруйними хімічними речовинами: сполуками важких і радіоактивних металів, особливо після Чорнобильської катастрофи, пестицидами. Через наявність великих водоймищ швидкість течії р. Дніпро зменшилась, що спричинює постійне «цвітіння» води внаслідок розмноження синьо-зелених водоростей, які виділяють токсичні речовини. Забруднення води в басейні р. Дніпро призвело до порушення природних процесів самоочищення водних об'єктів, що значно ускладнило проблему одержання якісної питної води на водогінних станціях, зокрема середньорічна концентрація забруднюючих речовин у Каховському водосховищі досягла: фенолів (канцерогени) $-1 \ldots 2$ ГДК, сполук міді - 6..11 ГДК, цинку - 7...12 ГДК. У той же час, як показали дослідження, стан водопровідних очисних споруд нині такий, що більшість хімічних сполук 3 води практично не усуваються, особливо коли їх вміст перевищує гранично допустимі концентрації. Проблема загострюється ще й тому, що існуючі технології питної води передбачають широке застосування хлору, зокрема для знешкодження продуктів розпаду фітопланктону, внаслідок чого в питній воді утворюється велика кількість токсичних канцерогенних сполук, що мають кумулятивну дію. Неякісна вода $\epsilon$ однією з причин того, що в останні роки в Україні спостерігається зростання рівня таких захворювань, як виразкова хвороба шлунка, жовчнокам'яна хвороба, хвороби органів дихання тощо [5].

Отже, через недбале ставлення до цієї водної артерії державного значення, велику кількість стічних вод низького рівня очистки, які скидають підприємства промислового й аграрного комплексів, р. Дніпро перебуває на грані екологічної катастрофи.

На думку директора Інституту колоїдної хімії і хімії води ім. А.В. Думанського НАН України академіка НАН України В.В. Гончарука, найбільш надійно захищеним від антропогенного впливу джерелом питного водопостачання є артезіанські підземні води. Підземні води менш схильні до сезонних коливань, краще захищені від небезпеки забруднення і зараження, більш рівномірно поширені на території, на відміну від поверхневих вод. Підземні води - складні багатокомпонентні системи, що включають цілий комплекс неорганічних і органічних речовин, газів, мікрофлори. Від умов їх формування залежить концентрація мінеральних солей у цих водах. 
Однак, незважаючи на те, що підземні води, на відміну від поверхневих, характеризуються загалом вищою якістю, вони можуть також не відповідати нормативним вимогам за вмістом окремих елементів. Тому для застосування таких вод для питних цілей необхідно здійснювати попереднє очищення.

На території України найбільшими артезіанськими басейнами $є$ Волинсько-Подільській, Дніпровсько-Донецький, Причорономорський. Глибина залягання артезіанських вод в Україні зростає з півночі $(100-200$ м) на південь (500-600 м). Артезіанська вода знаходиться на глибинних шарах землі i зазвичай виходить на поверхню під тиском. Її запаси зосереджені в межах западин, флексур або інших геологічних структурах, що утворюють таким чином артезіанські басейни.

Артезіанські води утворилися в дуже давні часи внаслідок геологічного руху земної кори. Вони не мають нічого спільного з грунтовими водами, крім того, що залягають у товщі землі. Проте артезіанські води мають певні переваги над поверхневими і грунтовими водами, оскільки розміщені між двома водонепроникними шарами, а тому захищені від потрапляння в них органічних забруднень. На склад артезіанських вод не впливають хімічні добрива та стічні води підприємств. Ці води не беруть участі в обміні 3 поверхнею Землі.

Якість артезіанської води залежить від складу пластів земної кори і часу їі залягання між ними. Серед недоліків цього типу вод слід відзначити те, що контакт з підземними мінералами збагачує їх різними солями, мікро- та макроелементами в концентраціях, що перевищують гранично допустимі (ГДК). Найчастіше в артезіанській воді міститься велика кількість заліза, марганцю, сірководню, вуглекислого газу, фтору. Для очищення від цих сполук зазвичай використовують аераційно-окисні методи 3 подальшою фільтрацією.

Мета статті: дослідження ефективності знезалізнення артезіанської води шляхом дискретно-імпульсного введення енергії в процесі аераційної обробки води та встановлення найбільш раціональних параметрів 3 урахуванням енергетичних і технологічних характеристик запропонованого способу.

Матеріали і методи. До основних аераційних методів знезалізнення води належать такі:

- «спрощена аерація» 3 подальшим фільтруванням крізь зернистий наповнювач;

- «глибока аерація» $з$ подальшим фільтруванням;

- метод «Віредокс».

Метод спрощеної аерації грунтується на здатності води, що містить залізо (II) і розчинений кисень, при фільтруванні крізь зернистий шар (пісок, антрацит, керамічну крихту) виділяти залізо на поверхні зерен, утворюючи каталітичну плівку з гідроксидів дво- і тривалентного заліза. Ця плівка активно інтенсифікує процеси окиснення і виділення заліза з води [6].

Для збагачення води киснем застосовують різні способи, наприклад вилив води 3 висоти 0,5 м в карман фільтра зі швидкістю 2,5-3 м/с. За стехіометричним співвідношенням на окиснення 1 мг заліза (II) витрачається 0,143 мг кисню. В установках знезалізнення для забезпечення досить високої швидкості хімічної реакції, відповідно до оптимальних параметрів фільтрувально- 
го завантаження, вміст кисню, розчиненого у воді, має становити $0,5-0,9$ мг на 1 мг заліза (II). У багатьох випадках для збагачення води повітрям раціональним виявляється застосування водоповітряного ежектора. Тиск (напір) на манометрі до ежектора — 320 кПа (3,2 атм), після ежектора - 80 кПа (0,8 атм). Продуктивність ежектора за повітрям - 7,2 м³/год. Витрати води $27 \mathrm{~m} 3 /$ год. Зі зростанням опору у фільтрувальному завантаженні і збільшенням протитиску після ежектора його продуктивність знижується [7].

При окисненні заліза (II) киснем у природній воді відбуваються такі фізико-хімічні процеси:

1) перенесення кисню крізь приграничний газовий дифузний шар до межі фаз вода-повітря;

2) перенесення кисню крізь примежовий шар води від межі фаз вода-повітря;

3) дифузія кисню в об’ємі води;

4) гомогенна реакція окиснення;

5) гідроліз солей тривалентного заліза.

Тож знезалізнення води є процесом масообміну, ускладненим хімічними реакціями. Швидкість хімічного перетворення визначається швидкістю транспорту речовини і теплоти до зони реакції і швидкістю реакції. Процеси масо- $\mathrm{i}$ теплообміну, які супроводжуються хімічною реакцією, можуть відбуватися в дифузійній, кінетичній або перехідній областях. У дифузійній області процес лімітується швидкістю транспорту теплоти і речовини в зоні реакції і реалізується за великих швидкостей хімічної реакції. Навпаки, процес, що відбувається в кінетичній області, лімітується швидкістю хімічної реакції і реалізується за великих швидкостей транспорту теплоти і речовини до зони реакції.

Результати і обговорення. Процес знезалізнення води залежить від швидкості реакції окиснення заліза (II) киснем повітря у водному розчині. Процес окиснення заліза (II) киснем повітря, у свою чергу, залежить від швидкості масопереносу (розчинення і доставки кисню) в дифузійній області. Інтенсифікація процесів масо- і теплопереносу досягається у разі дискретно-імпульсного введення енергії [8].

Для реалізації вищезазначеного методу в процесах очищення води в Інституті технічної теплофізики НАН України розроблено аераційно-окиснювальну установку роторного типу (АОРТ) (рис. 1) [9].

Очищення води за розробленою схемою здійснюється таким чином: артезіанська вода надходить у збірник-накопичувач (1), звідки потрапляє в аератор-окиснювач (2) у вигляді водно-повітряної суміші. В аераторі-окиснювачі відбувається насичення води киснем, а також частково перебіг реакцій окиснення $\mathrm{Fe}^{2+}$ до $\mathrm{Fe}^{3+}$ і гідролізу до $\mathrm{Fe}(\mathrm{OH})_{3}$. Після цього водно-повітряна суміш прямує до фільтраційно-окиснювальної колони (3), яка може бути заповнена піском або вугіллям різних фракцій. У колоні відбуваються процеси остаточного окиснення, гідролізу й очищення води від $\mathrm{Fe}(\mathrm{OH})_{3}$, що випав в осад. Після колони, очищена від заліза вода проходить крізь розпилювальний пристрій для видалення діоксиду вуглецю. Знезалізнена вода 3 нижньої частини збірника-накопичувача (1) через двоходовий кран (9) надходить до збірника очищеної води. 


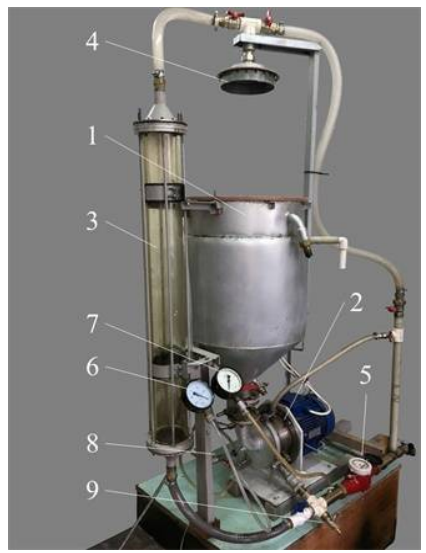

Рис. 1. Аераційно-окиснювальна установка роторного типу (АОРТ):

1 - збірник-накопичувач; 2 - аератор-окиснювач; 3 - фільтраційно-окиснювальна колона; 4 - розпилювальний пристрій; 5 - лічильник води; 6 - манометр;

7 - вакуумметр; 8 - кран подачі повітря; 9 - двоходовий кран

Слід зазначити, що знезалізнення води в установці відбувається в прямотоці як за один цикл обробки, так і в режимі рециркуляції для збільшення ступеня очищення води.

Установку АОРТ було використано на Червонослобідському спиртовому заводі концерну «Укрспирт». Для технологічних цілей на підприємстві використовують воду з артезіанських свердловин глибиною 200-250 м. За своїми фізико-хімічними показниками ця вода не відповідає вимогам ДСТУ на питну воду. Так, вміст заліза у досліджуваній воді досягав 3,5 мг/л, тоді як ГДК становить $0,3 \mathrm{мг} /$ л.

Під час проведення експерименту було досліджено вплив конструктивних особливостей роторно-пульсаційного вузла (РПВ) на ефективність знезалізнення води. Одним із показників, які впливають на характер гідродинамічних процесів в аераторі-окиснювачі, є кутова швидкість обертання ротора. В експерименті кутову швидкість ротора варіювали в межах $35 \ldots 55$ об/с. Початкова концентрація іонів заліза в об'єкті дослідження становила 3,5 мг/л. Графік залежності концентрації іонів заліза у воді від кількості циклів обробки за різних швидкостей обертання ротора наведено на рис. 2.

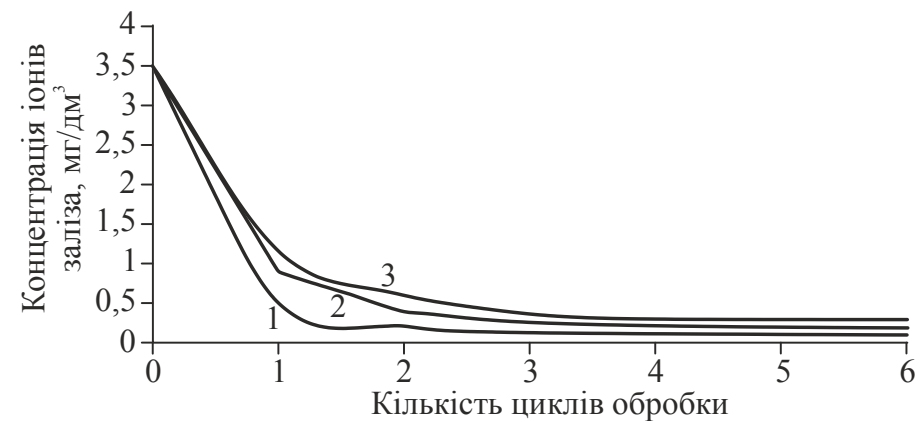

Рис. 2. Залежність зміни концентрації іонів заліза у воді від кількості циклів обробки за швидкостей обертання ротора: $1-55 ; 2-45 ; 3-35$ об/с 
Результати досліджень показали, що обробка води в аераторі-окиснювачі дає змогу ефективно зменшувати концентрацію іонів заліза у воді. Так, за кутової швидкості обертання ротора 55 об/с концентрація іонів заліза за один цикл обробки знижується з 3,5 до 0,25 мг/л. Зі зменшенням кутової швидкості до 45 та 35 об/с для досягнення бажаного результату $(\leq 0,3$ мг/л) необхідно збільшувати кількість циклів обробки.

Ротор в аераторі-окиснювачі має вигляд циліндра 3 поперечними щілинними отворами розміром 20,0×30,0 мм. Їх кількість становить 60 . Статор аналогічно ротору має таку саму кількість отворів. Зазор між статором і ротором 350 мкм. 3 огляду на конструктивні особливості статора і ротора воду в установці можна обробляти з різною частотою пульсацій, яка визначається добутком кутової швидкості обертання ротора на кількість отворів у роторі. На наступному етапі досліджень було встановлено залежність концентрації заліза від кількості циклів обробки з різною частотою пульсацій (табл. 1). Початкова концентрація іонів заліза у воді так само становила 3,5 мг/л.

Таблиця 1. Залежність концентрації заліза від кількості циклів обробки за різної частоті пульсацій

\begin{tabular}{|c|c|c|c|}
\hline \multirow{2}{*}{ Кількість циклів обробки } & \multicolumn{3}{|c|}{ Концентрація іонів $\mathrm{Fe}, \mathrm{мг/л} \mathrm{за} \mathrm{частоти} \mathrm{пульсацій}$} \\
\cline { 2 - 4 } & 2,0 кГц & 2,5 кГц & 3,0 кГц \\
\hline 1 & 1,50 & 1,00 & 0,20 \\
\hline 2 & 1,00 & 0,30 & 0,10 \\
\hline 3 & 0,70 & 0,25 & 0,10 \\
\hline 4 & 0,50 & 0,20 & 0,09 \\
\hline
\end{tabular}

Аналізуючи дані табл. 1, можна зробити висновок, що зміна частоти пульсацій потоку впливає на залишковий вміст іонів заліза в обробленій воді. Так, у разі обробки води 3 частотою пульсацій 3 кГц концентрація іонів $\mathrm{Fe}$ за один цикл зменшується від 3,5 до 0,2 мг/л. Зі зниженням частоти пульсацій до 2,5 кГц значення ГДК (0,3 мг/л) можна досягти за 2 цикли обробки. За подальшого зменшення частоти пульсацій до 2,0 кГц бажаний результат знезалізнення не досягається.

Ще одним критерієм оцінювання інтенсивності обробки води в аераторіокиснювачі $\epsilon$ швидкість зсуву потоку. Цей показник поєднує дві величини: швидкість руху потоку в радіальному напрямку та величину зазору між статором і ротором. Динаміку зміни концентрації іонів заліза у воді залежно від кількості циклів обробки за різної швидкості зсуву потоку наведено в табл. 2.

Таблиця 2. Залежність концентрації заліза від кількості циклів обробки за різної швидкості зсуву потоку

\begin{tabular}{|c|c|c|c|}
\hline \multirow{2}{*}{ Кількість циклів обробки } & \multicolumn{3}{|c|}{ Концентрація іонів $\mathrm{Fe}, \mathrm{мг} /$ л за швидкості зсуву потоку } \\
\cline { 2 - 4 } & $30 \cdot 10^{3} \mathrm{c}^{-1}$ & $40 \cdot 10^{3} \mathrm{c}^{-1}$ & $50 \cdot 10^{3} \mathrm{c}^{-1}$ \\
\hline 1 & 1,70 & 0,80 & 0,25 \\
\hline 2 & 1,10 & 0,30 & 0,10 \\
\hline 3 & 0,70 & 0,25 & 0,08 \\
\hline 4 & 0,25 & 0,15 & 0,08 \\
\hline
\end{tabular}


Дані, наведені в табл. 2, свідчать, що зі збільшенням швидкості зсуву потоку від 30 до $50 \cdot 10^{3} \mathrm{c}^{-1}$ ефективність знезалізнення води збільшується в 4 рази. Так, за швидкості зсуву потоку $30 \cdot 10^{3} \mathrm{c}^{21}$ для знезалізнення води від 3,5 до 0,25 мг/л необхідно 4 цикли обробки, а за швидкості зсуву потоку $50 \cdot 10^{3} \mathrm{c}^{-1}$ один.

Доведено, що, керуючи гідродинамічними параметрами та змінюючи конструкційні особливості РПВ аератора-окиснювача, можна регулювати динаміку і якість очищення артезіанських вод від сполук заліза.

У табл. 3 наведено результати експериментів 3 очищення артезіанської води від заліза, марганцю, сірководню, вуглекислого газу. Воду брали зі свердловини глибиною 250 м, що знаходиться в Київській області. Очистку проводили на установці АОРТ в один цикл за швидкості обертання РПВ 55 об/с і частоті пульсацій 3 кГц. Необхідно зазначити, що за цих режимів обробки вміст вказаних сполук після очистки не перевищує ГДК, встановлені як в Україні, так і в країнах $Є С$.

Таблиця 3. Показники якості артезіанської води до і після очищення

\begin{tabular}{|c|c|c|c|c|}
\hline Показники якості води & До очистки & Після очистки & ГДК* (Україна) & ГДК** $(С С)$ \\
\hline $\mathrm{Fe}$, мг/л & 5,2 & 0,17 & 0,3 & 0,2 \\
\hline $\mathrm{Mn}, \mathrm{мг} /$ л & 0,37 & 0,05 & 0,1 & 0,05 \\
\hline $\mathrm{H}_{2} \mathrm{~S}, \mathrm{мг} /$ л & 0,2 & 0,001 & 0,003 & 0,001 \\
\hline $\mathrm{CO}_{2, \mathrm{M}} /$ л & 56,7 & 3,5 & 4,0 & 3,5 \\
\hline $\mathrm{pH}$ & 6,0 & 7,2 & $6,5-8,5$ & $6,5-8,5$ \\
\hline
\end{tabular}

* Відповідно до ДСТУ 7525:2014 «Вода питна. Вимоги та контролювання якості». ** Відповідно до Директиви Ради 98/83/СС «Про якість води, призначеної для споживання людиною».

Для оцінки ефективності роботи установки було визначено іï енергетичні показники і проведено їх порівняльний аналіз. Найбільш близьким до запропонованої установки технічним рішенням є хвильовий гідродинамічний пристрій [10]. Для порівняння також обрано обладнання технології хімічного окиснення. Порівняльні показники роботи наведених пристроїв наведено в табл. 4.

Таблиия 4. Енергетичні показники роботи аераційно-окиснювальних пристроїв

\begin{tabular}{|c|c|}
\hline Пристрої & Питомі енерговитрати, кВт год/м ${ }^{3}$ \\
\hline Аераційно-окислювальні: & 4,50 \\
- хвильовий гідродинамічний пристрій & 0,30 \\
\hline - АОРТ & 5,54 \\
\hline
\end{tabular}

На основі проведеного аналізу можна зробити висновок, що застосування АОРТ для очищення води порівняно з вищезгаданими пристроями дає змогу знизити енерговитрати в $15 \ldots 20$ разів. Такий технологічний та енергетичний ефект очищення води в аераційно-окиснювальній установці роторного типу зумовлюється застосуванням методу дискретно-імпульсного введення енергії. Механізм дії установки АОРТ полягає в тому, що водоповітряна суміш, проходячи крізь щілинні отвори та зазори РПВ аератора-окиснювача, під- 
дається дії ударних хвиль, міжфазної турбулентності, мікрокавітації, кумулятивних струменів, вихорів, які спричинюють на міжфазних поверхнях нестійкості Релея-Тейлора або Кельвіна-Гельмгольца, що приводить до інтенсивного дроблення бульбашок повітря, значного збільшення сумарної поверхні контакту фаз та інтенсифікації процесів масо- і теплопереносу. Подібних ефектів, зазвичай, не вдається досягти при використанні традиційних методів обробки дисперсних середовищ навіть у разі значно більшого рівня питомих енерговитрат.

\section{Висновки}

1. Проведені дослідження підтвердили високу ефективність застосування методу дискретно-імпульсного введення енергії в процесі аераційної обробки води, що дає змогу інтенсифікувати процес ії очищення від іонів заліза та мангану в промислових умовах.

2. Застосування нового тепломасообмінного обладнання у вигляді аераційноокиснювальної установки роторного типу дає можливість інтенсифікувати процес підготовки питної і технологічної води та в кілька разів знизити енерговитрати.

\section{Література}

1. Крушенко Г.Г. Проблема воды / Г.Г. Крушенко, Д.Р. Сабирова, С.А. Петров, Ю.А. Талдыкин // Вода и экология. Проблемы и решения. -2000 . - № 3. - С. $2-8$.

2. Закон України «Про основні засади (стратегію) державної екологічної політики України на період до 2020 року» від 21.12.2010 № 2818-VI [Електронний документ]. Режим доступу : http://zakon3.rada.gov.ua/laws/show/2818-17.

3. Указ Президента України «Про заходи щодо визначення і реалізації проектів із пріоритетних напрямів соціально-економічного та культурного розвитку» № 895/2010 від 8 вересня 2010 року [Електронний документ]. - Режим доступу : http://zakon0.rada.gov.ua/laws/show/1256-2010-\%D0\%BF.

4. Гончарук В.В. Наука о воде / В.В. Гончарук. - Київ : Наукова думка, 2010. - 512 с.

5. Мягченко О.П. Основи екології. Підручник / О.П. Мягченко. — Київ : Центр учбової літератури, 2010. - $312 \mathrm{c}$.

6. Драгинский В.Л. Очистка подземных вод от соединений железа, марганца и органических загрязнений / В.Л. Драгинский // Водоснабжение и сантехника. — 1997. — № 12. C. $1-6$.

7. Золотова Е.Ф. Очистка воды от железа, марганца, фтора и сероводорода / Е.Ф. Золотова, Г.Ю. Асс. — Москва : Стройиздат, $1975 .-176 \mathrm{c}$.

8. Микро- и наноуровневые процессы в технологиях ДИВЭ: Тематический сборник статей /под общей ред. А.А. Долинского; Институт технической теплофизики НАН Украины. - Киев : Академпериодика, 2015. - 464 с.

9. Пат. України №114143 МПК (2016.01) C02F 9/00 C02F 1/64 (2006.01) Установка для аераційного знезалізнення підземних вод / А.А. Долінський, О.М. Ободович, Т.А. Резакова, А.М. Фіщенко; Заявка u2016 10091; заявл. 04.10.2016, опубл.27.02.2017, бюл. № 4.

10. Курбатов А.Ю. Интенсификация процесса очистки воды от железа с применением волновых гидродинамических устройств: дис. канд. техн. наук. 02.00.04. Москва, 2014. $118 \mathrm{c}$. 